\title{
Theological paradigms and conservative Afrikaners
}

\author{
H C G Robbertze \\ Theological School Afrikaans Protestant Church
}

\begin{abstract}
Papers published in the HSRC publication Paradigms and progress in theology (1988) reject foundationalistic theology and recommend a holistic theological approach. In this process contextual theology, which emphasises the distinctiveness of individual nations, is accused of being the 'domination paradigm' and is even called a heresy. This article aims to show that the holistic theological approach is also guilty of foundationalistic reasoning and intolerance. Furthermore, the need for a balanced theological paradigm for the conservative Afrikaner believer, who desires an own land for the Afrikaner nation is shown. Contextual theological reflection has not only a criticising function, but also a legitimising responsibility. The balanced contextual theological paradigm for conservative Afrikaner believers must be critical, legitimising and free of foundationalism.
\end{abstract}

In the Human Sciences Research Council's publication Paradigms and Progress in Theology (1988), the holistic theological paradigm is presented as an alternative to foundationalistic exclusivist theology. 'Holism is seen as progress in theological reasoning while it offers the possibility of moving away from foundationalism with its exclusivism in reasoning and its intolerance' (Mouton \& Pauw 1988:183).

The terms 'paradigm' and 'progression' in theological reasoning require further explanation.

Theology is practised from a variety of divergent ideologies. The divergent research traditions were referred to as scientific paradigms by Kuhn (1970:182vv). He described the term 'paradigm' as a 'disciplinary matrix'. He states that a paradigm is 'disciplinary because it refers to the common possession of the practitioners of a particular discipline...' (Kuhn 1970:182), and a paradigm is a "matrix" because it is 
composed of ordered elements of various sorts....' Vorster (1988:32) agrees with Kuhn's definition and states: 'The matrix forms the framework in which solutions are sought for acknowledged problems, and problems are solved.' A paradigm can be referred to in the following context: The methods and ways in which problems are solved are certain. Members of the scientific community share common beliefs, they have a similar world view and use the same concepts in explaining problems they investigate' (Vorster 1988:33). A theological paradigm can therefore be defined as 'die samehangende geheel van grondoortuigings, modelle en teorieë wat as omvattende interpretasiekader in die beoefening van Teologie funksioneer' (Van Huyssteen 1987:7).

Van Huyssteen (1987:206), in his search for criteria for a trustworthy systematic theological rationality model, believes that the rationality of theological judgements, theories and ideologies depends on the ability of theory choices to reduce or solve problems - empirical or conceptual. The rationality of a specific theory is described in terms of the progressivity of the theory. Progress as the criterion for rationality in theological reflection relates to the ability of a theological paradigm to solve problems.

Holism is seen as progress in theological reasoning while it offers the possibility of moving away from foundationalism with its exclusivism in reasoning and its intolerance. Mouton \& Pauw (1988:183) point out that holism is an interesting alternative to foundationalism. Sentences that form part of a theory are always part of a bigger whole. Together they form a single interwoven web of belief or context. Individual sentences cannot thus be verified or falsified on their own. They are always part of a bigger whole, a theory. Eventually no sentence in a theory is completely immune from revision. The inevitable result of Mouton \& Pauw's reasoning is that all proposed holistic theological solutions are comparable (Mouton \& Pauw 1988: 184). In this sense, they are of the opinion that we have progress while holism moves away from the intoleristic tendencies of foundationalism.

The progress-claim of holism goes hand in hand with the claim of moving away from any kind of individualism. In holistic thinking the emphasis is placed on the whole rather than the individual parts. This tendency is evident in the reflection on exegetical-methodological thinking. According to Vorster (1988:32) we are, exegetic-methodological speaking, heading towards a phase where the historico-critical approach with its focus on the parts is going to be displaced by a holistic paradigm with its focus on the whole. 


\section{CRITICISM ON THE SO-CALLED FOUNDATIONALIST EXCLUSIVIST REASONING IN CONTEXTUAL CONSERVATTVE AFRIKANER BELEF}

Not only are certain approaches in the scientific community being accused of foundationalism with its exclusivism, but contextual conservative Afrikaner belief is also accused of foundationalism with its exclusivism. The foundationalist exclusivism that is criticised here is not the exclusivist approaches of an individual, but rather the view of a certain group of people in South Africa. The criticism is about 'a set of beliefs and attitudes' that are manifested by the beliefs of conservative Afrikaners.

Deist (1990:124-139), by applying West's definition of civil religion, as 'a set of beliefs and attitudes that explain the meaning and purpose of any given political society in terms of its relationships to a transcendent, spiritual reality, that are held by the people generally of that society, and that are expressed in public rituals, myths, and symbols' (Deist 1990:126), is of the opinion that Afrikaner civil religion was born in the social context of the Afrikaners during the 1930s and 1940s. He points out that the former farm owners had, via urbanisation and the coupled social circumstances of finding themselves at the bottom of the social ladder and experiencing a new competition with former black farm workers, made use of foundationalism as their theological paradigm and Kuyperianism as their cultural model (Deist 1990:129) to explain their circumstances and ideals.

Edwards (1988:242) speaks of the 'domination paradigm' where 'separation' is encouraged. She presents the 'communion paradigm' as an alternative (Edwards 1988:243). Afrikaner nationalism that emphasises separation is seen as contra-productive individualism. The paradigm of individualistic contra-productive nationalism contrasts with the holistic 'communion paradigm', and is called a 'heresy'.

Krüger (1988:220) argues that we must progressively overcome limitations and partiality, and that we have to attain a disinterestedness as far as possible to get to an 'ethic of universal solidarity, responsibility and compassion'. Edwards (1988:239) states that theologies are justified when 'they facilitate development, integration and wholeness of persons and societies'. Holism thus becomes a philosophy of life where 'human unity' serves as political model.

\section{FOUNDATIONALIST TENDENCIES IN HOLISTIC APPROACHES}

I want to admit that most Afrikaner conservative reasoning in favour of separateness is based on foundationalist reasoning. However, the question may also be put whether politico-theological-holistic-approaches are really moving away from foundationalism. 
It seems to me that the same accusation of foundationalism might be applicable to exponents of holistic politico-theological reasoning as well as exponents of liberation theology.

What approach in foundationalism is it against which holism reacts? In reducing foundationalism to its simplest form, Mouton \& Pauw (1988:177) establish three claims:

- The elements of knowledge are divided into two classes, namely basic propositions and non-basic propositions;

- The truth or acceptability of the non-basic propositions, however interpreted, is guaranteed by their being grounded in the basic propositions;

- Basic propositions are non-inferential (immediate) and indubitable, and therefore, form the foundation of knowledge.

Mouton \& Pauw (1988:180) indicated that both Bacon and Descartes infused their thoughts with a belief in the divine source of knowledge. Both aimed at arriving at knowledge which is guaranteed by divine authority. This kind of reasoning resounded in the Reformed tradition, where basic propositions in Scripture imply non-basic propositions of theology.

According to Mouton \& Pauw the weak point in this mode of reasoning lies in the grounding of one proposition in another. It means that the truth of one proposition (non-basic) is dependent on the truth of another or others (basic propositions). It is the truth of the one that makes the other true (Mouton \& Pauw 1988:181). The question is put: 'How does a basic proposition in Scripture imply a non-basic proposition of theology?' (Mouton \& Pauw 1988:181). Thus, in the end it is a question of implication. The relationship between the elements of the two classes of propositions is a truth-functional one, namely of implication. Proposition A is implied by the truth of another proposition, B. 'It involves making a non-deductive inference, i.e. it is supported by the antecedent but is not derived from it' (Mouton \& Pauw 1988:181-182).

When the explanation of Mouton \& Pauw is taken as a criterion of foundationalism, we can measure holism against it.

Notice must be taken of the fact that Vorster (1988:45), in his exegetic-methodological approach, when putting the emphasis on the 'whole', says that there is a search for a uniform paradigm within which 'normal' science can be practised. It seems as if any kind of atomistic approach is going to be viewed as abnormal. The uniform paradigm will be the sjebolet for any methodology in exegetical practices.

The question may be asked: Are we not on our way to a new form of foundationalism with its dogmatic absolutism? It does sound very close to the foundationalism of which Mouton \& Pauw speak. The truth of the proposition that atomistic 
approaches are abnormal $(\mathrm{A})$ is implied by the proposition that the holistic approach is the normal uniform paradigm (B) (Mouton \& Pauw 1988:181):

$\mathbf{B}$ implies $\mathbf{A}$

$B$ is basic

Thus $A$ is true.

Where Scripture has been the certain and indubitable basis of knowledge, the holistic uniformed paradigm forms the new inspired and error-free authority. This authoritative holistic mode of thinking has sedimented in politico-theological reasoning.

Krüger (1988:220) argues that we must progressively overcome limitations and partiality, and that we have to attain a disinterestedness as far as possible to reach an 'ethic of univeisal solidarity, responsibility and compassion'.

Edwards (1988:239) goes even further when she authoritatively claims that theologies are 'justified' when 'they facilitate development, integration and wholeness of persons and societies'. 'Interconnectedness' is the passport to 'genuine transformation' (Edwards 1988:248) and it is 'only the free, only those who are liberated and humanized in this way, who can liberate' (Edwards 1988:249).

Again we meet pronouncements of 'only'-interconnectedness. Individualism is seen as breeding and reinforcing racism and ideological separatism (Edwards 1988: 246). Are we at a point in holistic thinking that claims of tolerance towards other viewpoints can be made?

Even Van Huyssteen, when writing about progress in theology, shows this kind of foundationalist intolerance in his reasoning. When discussing progress in theology he reasons that the rationality of theological pronouncements depends on the question of whether there is any progress in so far as problems have been lessened or solved (Van Huyssteen 1987:206). The contextualising of theological problems, such as the question concerning the visible unity of the church, and specifically the question of whether apartheid as a political system is not fundamentally heretical, is seen as valid progress in systematic theology (Van Huyssteen 1987:207). Two concepts, 'unity' and 'apartheid', are used. One is used in a positive sense, as if there will be progress when the unity of the church is really visible, while the other is used in a negative sense, as if there will be progress when it can be theologically shown that apartheid as a political system is fundamentally heretical. By suggesting that apartheid as a political system could be heretical, Van Huyssteen (1987:207) discloses an attitude of unsympathetic intolerance. Surely it would be unfair to catagorise him, and accuse him of holistic reasoning and intolerance on the basis of his suggestion. However, when this suggestion is seen against the background of the intolerance of foundationalist holistic thinking, my meaning may become clear. 


\section{THE IDEAL AND THE REALTTY}

It is interesting that both Krüger and Edwards acknowledge that individuality is part of reality. Krüger (1988:214) speaks of 'the internal pluralism of religions, the factions and schools', and Edwards (1988:247) of ideological structures that 'are interwoven with our various theological and philosophical theories and value systems'. However, both of them want this reality to apply to an idealistic holistic world. Krüger (1988:214) is of the opinion that these pluralisms are polishing one another and by way of inter-religious dynamics the ideal of a stabilised final synthesis is attainable. Likewise Edwards (1988:249-250) has the ideal of a new humanity of intercultural and interconfessional human experience: 'In such interpersonhood domination falls away, conflicting worlds come together, and authentic fusion of horizons can take place, with all that that can mean for justice and peace' (Edwards 1988:250).

However, it is not the ideal that constitutes real progressive theological reasoning. It is the answers given to real faith questions of a community that turn theological reflection into theological reasoning.

Heyns \& Jonker (1973:128-131) describe theology as the systematic scientific reflection of that which takes place in the pre-theological and pre-scientific stages of religious reflection. Van Huyssteen (1987:1) asks the question: 'Wat presies gebeur in die proses van teorievorming waarin ons alledaagse geloofstaal skynbaar getransformeer kan word tot teologiese teorie wat inderdaad daarin sou kon slaag om sowel op ons insig as op ons ervaring te appelleer?' Real progress in theology cannot be attained by idealistic paradigms, but only by moulding pre-theological and prescientific everyday faith language into scientific theological theories. Faith questions are being put into a certain context. Answers will only be satisfactory and progressive when the context into which these faith questions were put is taken into account.

According to Van Huyssteen (1987:173f) the reality-involvement of theological claims is the first criterion for a valid systematic-theological rationality model. Smit (1988:107) agrees with Van Huyssteen but points out that, even though Van Huyssteen refers to the social context of theology, he avoids analysing this reality-related context. He accuses Van Huyssteen of neglecting 'social and political issues as part of the reality on which theology ought to be directed' (Smit 1988:103).

The question may be asked whether we are not busy explaining away the resultant subjectivism. In trying to avoid this pitfall Hefner (1988:11) makes a distinction between 'christian theological statements' which 'may be viewed in their function of articulating the experience of the community of faith in which they originate' and theological statements that must be viewed 'in their function of conjoining the articulation of the faith-community's experience with certain configurations of empirical 
data that pertain to human beings in general, so as to illuminate those data and thus provide explanation and interpretation of the data. In this function theological statements extend their significance from the community to general human experience'. According to him 'theology's claim to convey truth and/or genuine knowledge is directly related to its success in accomplishing the wider explanatory function' (Hefner 1988:12).

One can agree with Hefner's point of view in that all contextual theology will be submitted to the test of time and, in the end, the criterion will be whether the paradigm had a wider explanatory function for human experience in general.

Theologies that have stood the test of time, because they had a wider explanatory function for human experience in general, are found in Scripture. Deist (1988: 335-346) showed that these theologies sometimes contradict each other. However, the different theologies have stood the test of time while each of them had, and still has, a message for general human experience. They were taken up in the canon because they succeeded in accomplishing a wider explanatory function. However, part of their success is also the fact that they originated in the real human experience of individuals or individual societies with their particular experiences.

Prozesky (1988:265) says that we need a progressive, critical paradigm that is the product of scientific and humane - rather than ecclesiastical and political - priorities. According to him this is not a 'rejection of realism, but a plea for a more subtle and humane form of it' (Prozesky 1988:266).

The following question may be posed: Is it by any means possible to create a paradigm free of any such priorities? The new hermeneutics has pointed out that the ideal of 'vorverständlose' understanding is impossible. Part of any kind of understanding is the pre-understanding that we have. Even the paradigm which is 'freed', as it were, from ecclesiastical and political priorities has the 'more subtle and humane form' of political and ecclesiastical holistic priorities. The difference is that paradigms which acknowledge their own political and ecclesiastical priorities, are at least related to reality.

The reality-orientated reflection will always be done from within real social and political situations. Religious convictions always find contextual expression (Deist 1990:126).

Social, ecclesiastical and political priorities will be part of religious reflection and the resulting paradigms. Individualism, as a result of different social, ecclesiastical and political circumstances, will not and cannot be reasoned away.

When one tries new methodologies there will always be different paradigms. Scientific theological research will always be done from certain points of view. The 
sociological context of the researcher will influence his reasoning and the theological questions that he must answer will always come out of a specific society.

Although contextualised theology is perhaps more related to reality and can possibly stand the test of time in its accomplishing wider explanatory function, it must be said (negatively) that the problems of foundationalism and individualism are not solved. Most contextual theologies of our time are based on chosen individual texts or text-complexes, out of the Old and/or the New Testament. In South Africa the blacks, with liberation theology, claim that God sides with the poor in their struggle for freedom against the oppressive whites. They put all the emphasis on the events of the history of Israel during the Exodus. On the other hand we have the right-wing Afrikaners with the vision that they are the chosen Israel. These people emphasise the concept of election in the Old Testament. The Bible is used foundationalist manner by both these views. Bible texts are used in an eclectic manner, and fundamental points of view are formed that suit the practitioners of the different points of view. What is true of the liberation- and white-contextualised theologies is also true of the current debate between the 'unity-seekers' and the 'separate churchgoers' in the ranks of the Afrikaner believers. In arguments both parties use biblical texts as their fundamental points of departure. The foundationalist holistic and foundationalist individualist points of view can be distinguished in both arguments.

\section{BAIANCED THEOLOGICAL PARADIGMS}

The present dualism between foundational holism and foundational individualism reminds one of the two contending elements in the reasoning of the post-exilic Jewish community, when there was the element of realism on the one hand, and the element of vision on the other hand. According to Hanson (1979:29-30),

[t]hese two elements...constitute the heart of all ethical religions. The visionary element is the vision of a divine order transcending all mundane institutions and structures, a vision which constantly calls those institutions and structures under judgment, stubbornly refusing at the same time to become identified with them. The element of realism is concerned with the day-to-day maintenance of those same mundane institutions and structures, and with preserving continuity so as to assure a context for the continued life of the community. When separated from the realism the vision leads to a retreat into the world of ecstasy and dreams and to an abdication of the social responsibility of translating the vision of the divine order into the realm of everyday earthly concerns. When separated from the vision the realism becom- 
es a sterile preserver of the status quo which absolutizes and eternalizes the existing order together with all of its inequities.

He continues: 'The history of Yahwism in the post-exilic period is the history of tension and struggle between those two elements which often led to their polarization' (Hanson 1979:30).

In the struggle for a new progressive theological paradigm we experience to a certain extent the same kind of tension between the visionary element and the element of realism. Foundationalist holistic reasoning represents the visionary element, and foundationalist individualist contextualised reasoning represents the element of realism.

Hanson (1979:23-30) points out that in Israel's religious history the prophets stubbornly integrated realism and vision into an highly creative force. It was especially Deutero-Isaiah who succeeded in bringing about the balance between these two elements.

\section{AN ATTEMPT AT CONSTRUCTING A BALANCED CONSERVATIVE AFRIKANER POLITICO-THEOLOGICAL PARADIGM}

In trying to find a way out of the theological impasse in which we find ourselves we must try to integrate realism and vision. This also implies getting rid of intolerant foundationalism. How we are going to achieve it remains an open question. Van Huyssteen (1987), with his realisation that we use metaphoric language in theological reflection, opens the possibility of 'kritiese geloofsverantwoording'. We also have to acknowledge the fact that the conservative Afrikaner theological paradigms, based upon the Kuyperian cultural model, where white domination over blacks was propagated on a foundationalist basis, never succeeded in finding significance for general human experience. Hefner's idea (1988:11-12) was that theological statements should be viewed in their function of conjoining the articulation of the faithcommunity's experience with certain configurations of empirical data that pertain to human beings in general, so as to illuminate those data and thus provide explanation and interpretation of the data. In this context theological statements extend their significance from the community to general human experience, which is applicable in this sense. Contextual Kuyperian Afrikaner theology failed to convey truth and/ or genuine knowledge that could successfully accomplish the wider explanatory function.

Let us start by asking what the faith questions being put by the conservative Afrikaner believer are. The basic question is whether he can have a country in which he can govern himself. Surely there are many conservative Afrikaners who believe in the answers that they get out of the bible. But all these 'faith answers' are 
basically an answer to the faith question: 'Can we have a land of our own where we can govern ourselves?'

Turning to the Bible for an answer to the question of whether a nation (as a particular individual group) has the right to ask for its own country, we see that most of the promises that God gave to Israel had to do with land and descendants. The New Testament does not give an answer to this question, but we must remember that the New Testament gave faith answers to another set of faith questions. The contextual faith question needs a contextual faith answer. In analysing, as far back as 1904, the character of the Afrikaner who fought against British imperialism, Andricssen (1903-1904:1) stated: '[D]e meest naar voren tredende eigenschap van den Boer is zijn zucht naar vrijheid.' We often hear of the fears of the whites in South Africa. I think that we also have to take cognisance af the fact that it is not only fears that are at stake, but also the determination of the Afrikaner to protect his right to govern himself. He did it previously in history, and he will do it again. His leaders gave him contextual faith answers in the past to do exactly this, and in the modern context he asks his theologians to give him similar answers to do the same. The neglect on the part of Afrikaner theologians to answer their own people's faith questions leads to all kinds of theological outgrowths, such as the so-called Israel vision. This vision, which propagates the supremacy and election of the Afrikaner, is the result of a legitimising theology without leaving itself open to the critical prophetic idealistic element of which Hanson (1979) spoke.

Liberation theology opened people's eyes as to their right to liberate themselves from physical oppression. It is strange that this right is aknowledged for all people, but the Afrikaner is only expected to liberate himself from his ideas. The Afrikaner certainly also has a right to physical freedom.

In an attempt to obtain a balanced contextual paradigm for the conservative Afrikaner believer, we must also keep in mind the need for success in accomplishing the wider explanatory function of which Hefner (1988:11-28) spoke. In this regard it is interesting that the freedom struggle of the Soviet nations has found approval all over the world. National sentiments are honoured all over the world. There is not only a need for contextual faith answers to be given to the Afrikaner society, but individual nations also need well-balanced non-foundationalistic contextual faith answers in response to the faith question: 'May we ask God whether this particular nation is entitled to its own country, and has this nation the right to govern itself?' 
Works cited

Andriessen, W F 1903-1904. Gedenkboek van den oorlog in Zuid-Afrika. Kaapstad: HAUM.

Deist, F E 1988. Prophet and society in transition, in Mouton, J, Van Aarde, A G \& Vorster, W S (eds), Paradigms and progress in theology, 335-348. Pretoria: HSRC. (HSRC studies in research methodology.)

--- 1990. Notes on the context and hermeneutic of Afrikaner civil religion. Missionalia $18 / 1,124-139$.

Edwards, F 1988. Cutting through contending ideologies: The new paradigm and the new commandment, in Mouton, J, Van Aarde, A G \& Vorster, W S (eds), Paradigms and progress in theology, 239-251. Pretoria: HSRC. (HSRC studies in research methodology.)

Hanson, P D 1979. The dawn of apocalyptic. Revised Edition. Philadelphia: Fortress.

Hefner, P 1988. Theology's truth and scientific formulation, in Mouton, J, Van Aarde, A G \& Vorster, W S (eds), Paradigms and progress in theology, 11-28. Pretoria: HSRC. (HSRC studies in research methodology.)

Heyns, J A \& Jonker, W D 1973. Op weg met die teologie. Pretoria: NG Kerkboekhandel.

Kuhn, T S 1970. The structure of scientific revolutions. 2nd ed. Chicago: University of Chicago.

Krüger, J S 1988. Conditionality, religious experience and conceptualisation, in Mouton, J, Van Aarde, A G \& Vorster, W S (eds), Paradigms and progress in theology, 209-222. Pretoria: HSRC. (HSRC studies in research methodology.)

Mouton, J \& Pauw, J C 1988. Foundationalism and fundamentalism: A critique, in Mouton, J, Van Aarde, A G \& Vorster, W S (eds), Paradigms and progress in theology, 176-186. Pretoria: HSRC. (HSRC studies in research methodology.)

Prozesky, M 1988. Methodological issues arising from the experience of religion as oppressive, in Mouton, J, Van Aarde, A G \& Vorster, W S (eds), Paradigms and Progress in theology, 259-267. Pretoria: HSRC. (HSRC studies in research methodology.)

Smit, D 1988. Theology as a critical account of personal faith?, in Mouton, J, Van Aarde, A G \& Vorster, W S (eds), Paradigms and progress in theology, 91-112. Pretoria: HSRC. (HSRC studies in research methodology.)

Van Huyssteen, W 1987. Teologie as kritiese geloofsverantwoording. 2de druk. Pretoria: RGN. (RGN-studies in navorsingsmetodologie 2.)

Vorster, W S 1988. Towards a post-critical paradigm: Progress in New Testament scholarship?, in Mouton, J, Van Aarde, A G \& Vorster, W S (eds), Paradigms and progress in theology, 31-48. Pretoria: HSRC. (HSRC studies in research methodology.) 
